\title{
A REVIEW ON THE ECOLOGICAL DETERMINANTS OF AEDES AEGYPTI (DIPTERA: CULICIDAE) VECTORIAL CAPACITY
}

\author{
Rafael Maciel-de-Freitas ${ }^{1}$ \\ 'Fundação Oswaldo Cruz (Fiocruz), Instituto Oswaldo Cruz, Laboratório de Transmissores de Hematozoários, Pavilhão Carlos Chagas, sala 414, $4^{\circ}$ \\ andar, Rio de Janeiro, RJ, Brasil. CEP: 21040-360 \\ E-mail: freitas@ioc.fiocruz.br
}

\begin{abstract}
Dengue is a re-emerging infectious disease that infects more than 50 million people annually. Since there are no antiviral drugs or vaccine to disrupt transmission, the most recommended tool for reducing dengue epidemics intensity is focused on intensify control efforts on its vector, the yellow fever mosquito Aedes aegypti. In order to better understand vector biology and its impact on disease transmission, a known concept in entomology and epidemiology is vectorial capacity, which refers to the ability of a mosquito to transmit a given pathogen. The variation of several aspects of mosquito biology, such as its survival, vectorial competence and biting rates can change the intensity of dengue transmission. In this review, the parameters used for composing the vectorial capacity formulae were detailed one by one, with a critical point of view of their estimation and usefulness to medical entomology.
\end{abstract}

Keywords: Dengue; yellow fever; disease transmission; dispersal.

\section{RESUMO}

UMA REVISÃO DOS DETERMINANTES ECOLÓGICOS NA CAPACIDADE VETORIAL DE AEDES AEGYPTI (DIPTERA: CULICIDAE). A dengue é uma doença infecciosa re-emergente que afeta mais de 50 milhões de pessoas anualmente. Uma vez que não existem drogas antivirais ou vacinas para interromper a transmissão, a ferramenta mais recomendada para reduzir a intensidade de epidemias de dengue é a intensificação de esforços de controle do seu vetor, o mosquito Aedes aegypti, também vetor da febre amarela urbana. A fim de entender melhor a biologia do vetor e seu impacto na transmissão da doença, um conceito conhecido em entomologia e epidemiologia é a capacidade vetorial, que se refere à habilidade de um mosquito em transmitir um dado patógeno. Nesta revisão, os parâmetros utilizados para compor a fórmula da capacidade vetorial foram detalhados um por um, com um ponto de vista crítico sobre a obtenção de suas estimativas e utilidade para a entomologia médica.

Palavras-chave: Dengue; febre amarela; transmissão da doença; dispersão.

\section{RESUMEN}

UNA REVISIÓN SOBRE LOS DETERMINANTES ECOLÓGICOS DE LA CAPACIDAD VECTORIAL DE AEDES AEGYPTI (DIPTERA: CULICIDAE). El dengue es una enfermedad infecciosa re-emergente que afecta más de 50 millones de personas anualmente. Al no existir drogas antivirales o vacunas para interrumpir la transmisión, la herramienta más recomendada para reducir la intensidad de epidemias de dengue es la intensificación de los esfuerzos de control de su vector, el mosquito Aedes aegypti, también vector da fiebre amarilla urbana. Con el objetivo de entender mejor la biología del vector y su impacto en la transmisión de la enfermedad, un concepto conocido en entomología y epidemiologia es la capacidad vectorial, que se refiere a la habilidad de un mosquito para transmitir dado patógeno. En esta revisión, los parámetros 
utilizados para componer la fórmula de la capacidad vectorial fueron detallados uno por uno, con un punto de vista crítico sobre la obtención de sus estimativas y utilidades para la entomología médica.

Palabras clave: Dengue; fiebre amarilla; transmisión de enfermedades; dispersión.

\section{BACKGROUND}

The World Health Organization (WHO) estimates that around 2.5 billion people lives in areas with risk of dengue transmission, with 50-100 million dengue infections per year mainly in endemic countries (Nathan \& Dayal-Drager 2007). Despite almost half of human population lives under risk of dengue infection, dengue cases are often restricted to the urbanized areas in the tropics (Rigau-Pérez et al. 1998).

The primary dengue vector worldwide is the yellow fever mosquito Aedes aegypti. This specie lives in close association with humans, lay eggs preferentially in man-made containers located inside or in the domestic areas of human dwellings and have an antropophilic and endophilic blood-feeding behavior (Peryassú 1908, Cunha et al. 2002, Braks et al. 2003, Maciel-de-Freitas et al. 2007a). Dengue transmission occurs during the heamatophagy of female mosquitoes, when nutrients present in the blood meal are used for ovarian development and embryogenesis (Lea et al. 1956, Clements 1999). During the blood meal, Ae. aegypti females inoculates dengue virus in a human host (that might be susceptible or not), an event that would possibly trigger a dengue infection.

Dengue is an infectious disease that has humans, dengue viruses and Ae. aegypti mosquitoes as its components. Thus, seems reasonable to expect that variations in the bionomics of one of these components might have a significant impact on disease transmission. For instance, different levels of human herd immunity may alter the impact of a dengue virus introduction and the course of infection since part of the population would not be susceptible to this pathogen (Focks et al. 2000). Similarly, dengue virus serotype, or even genotypes within serotypes, may have different levels of virulence, also affecting the intensity of dengue transmission (Rothman 1997, Holmes \& Burch 2000).

By assuming herd immunity and virus virulence not vary, the intensity of disease transmission would then be influenced by the mosquito vector population. In the field of entomology, malariologists were the pioneers in the development of methods to measure the rate of disease transmission by bloodsucking vectors (Warrel \& Gillies 2002). During the 1960s, Garret-Jones devised the Vectorial Capacity, what would be the average number of secondary cases of a disease (e.g. malaria, dengue) arising from each primary infection in a defined population of susceptible hosts (Garret-Jones 1964). In other words, the vectorial capacity represents the ability of a mosquito population in transmitting an infectious agent (Klempner et al. 2007). The usual formula for vectorial capacity is:

$$
V C=\frac{m b c a^{2} P^{n}}{-\operatorname{Ln}(P)}
$$

Where $a$ is the biting rate per human per day; $b$ is the probability of an infected mosquito transmit the pathogen to a susceptible host during biting; $c$ is the probability of a mosquito get infected when biting an infected host; $m$ is the number of adult female mosquitoes per person; $n$ is the duration of the extrinsic incubation period of pathogen; $P$ is the mosquito daily survival rate and $V C$ is population vectorial capacity.

For the Ae. aegypti - dengue virus system, it has been shown that the probability of daily survival (PDS) and the extrinsic incubation period (EIP) are the most important parameters of Ae. aegypti vectorial capacity (Luz et al. 2003).

The principal aim of this review is to enrich the debate about dengue transmission dynamics with a critical view of the ecological determinants of $A e$. aegypti vectorial capacity.

\section{BITING RATE}

The Ae. aegypti mosquito lives in close association with human beings, with a remarkable preference of blood-feeding on human blood (Scott et al. 1993, 
2000). It was observed in Thailand that Ae. aegypti females rarely feed on sugar, obtaining the energy to sustain their metabolism strictly from bloodsucking (Edman et al. 1992). In fact, females that feed more often on a blood source have an evolutive advantage in comparison with those that feeds on sugar plus blood, because the former has higher fecundity (Day et al. 1994, Scott et al. 1997, Naksathit et al. 1999a, 1999b, 1999c).

The biting rate of a disease vector is a crucial component in the determination of its vectorial capacity. Intuitively, an increase on mosquito biting rate would impact considerably the contact rate between vector and hosts, what would finally enhance disease transmission. It is worth to remind that in vectorial capacity formulae proposed by Garret-Jones (1964), the biting rate is the unique parameter that appears twice. The main explanation for this relies on the fact that a female mosquito must bite at least twice to transmit the pathogen, the first to achieve infection and the second to transmit it (Service 1993). This statement might be true for the Anopheles - malaria system, but not be as precise for Ae. aegypti - dengue virus interaction, since dengue may be transmitted vertically by females to their offspring (Thenmozhi et al. 2000, Arunachalan et al. 2008). It is often assumed vertical transmission may play a significant role in the maintenance of dengue viruses in nature, but its occurrence under natural conditions have rarely been evaluated in the field (Thenmozhi et al. 2000, Arunachalan et al. 2008).

In field experiments conducted in Thailand, it was noticed that multiple feeding behavior of Ae. aegypti females varies seasonally, with an increasing activity corresponding to the epidemic season (Scott et al. 1993). However, major questions as rather infected mosquitoes have any change in their blood-feeding behavior still needs further evaluation (Kuno 1995). Two previous studies, with controversial results, have evaluated the impact of dengue virus in the biting behavior of infected Ae. aegypti. In the first one, a mosquito population that was maintained in laboratory for at least fifteen years was infected with DENV-2 and the authors not observed any influence of infection on the biting behavior of Ae. aegypti, especially on vector ability to locate and imbibe blood from an uninfected host (Putnam \& Scott 1995). On the other hand, Platt et al. (1997) used a field population of infected mosquitoes intrathoracically with DENV-3 and observed that the time spent during haematophagy and the time spent to start bloodfeeding were higher in the infected individuals than on those uninfected. Previous reports have shown parasite-induced effects on the feeding behavior of mosquitoes infected with Rift Valley Fever virus and on mosquitoes feeding on mice infected with malaria parasites (Day \& Edman 1983, Day et al. 1983, Rossignol et al. 1985, Turell \& Bailey 1987). One potential source of bias in estimating biting rate relies if vectors preferentially feed on infected rather than uninfected hosts, as observed (Day et al. 1983, Dye 1990).

Other possible confounding factor that may alter the feeding behavior of Ae. aegypti is mosquito body size. The size of an adult Ae. aegypti is a late manifestation of larval habitat quality (Nasci \& Mitchell 1994). Females from well-fed larvae emerge with lipid reserves adequate to develop ovaries to stage II, with the result that the first blood meal is sufficient to complete oogenesis (MacDonald 1956). Thus, small females tend to blood-feed more often due to the absence of nutritional reserves to their metabolism, probably due to a low-nutrient larval habitat (Nasci \& Mitchell 1994, Scott et al. 2000).

\section{PROBABILITIES OF GETTING INFECTED AND OF DENGUE TRANSMISSION}

Laboratory experiments have been used to show the influence of high geographic variation in vector competence, i.e. susceptibility of $A e$. aegypti to dengue virus (Gubler \& Rosen 1976). The susceptibility or refractoriness of Ae. aegypti populations to dengue virus is historically defined as the intrinsic permissiveness of mosquitoes to infection, replication, and transmission (Hardy 1988, Woodring et al. 1996). When a mosquito takes a viraemic bloodmeal, dengue virus immediately encounters several barriers to infection. The first barrier dengue virus has to surpass, and probably the most effective one, is the midgut infection barrier, a physical and chemical barrier mainly composed by midgut cells and digestive enzymes. The level of dengue infection is a quantitative rather than a discrete variable that appears to be distributed 
continuously among individuals or populations and it is subject to environmental effects (Bosio et al. 2000).

Genetic studies of vector competence have primarily used strain selection in laboratory to produce susceptible and resistant lines to dengue infection (Miller \& Mitchell 1991). In Brazil, the susceptibility of Ae. aegypti to dengue virus was observed for 23 localities distributed in thirteen Federal Units (Lourenço-de-Oliveira et al. 2004). Authors have shown that field populations are often highly susceptible to DENV-2, with a significant geographic variation on vector competence. This heterogeneity in vector competence of field populations might be exemplified by the contrast of the population of Milhã, CE, where just $21.57 \%$ of individuals were susceptible to DENV-2, and the population of Boa Vista, RR, where $99.02 \%$ were infected (Lourençode-Oliveira et al. 2004). Thus, the reasons to explain this heterogeneity in vector competence are great relevance to the study of vector-borne diseases.

In some previous dengue models, authors have pointed that the probability of a bite infects a susceptible human and a mosquito as 0.75 each (Newton \& Reiter 1992, Atkinson et al. 2007). In order to estimate these values precisely, several aspects must be considered, such as human herd immunity, virulence of DENV strains, asymptomatic dengue cases and the number of bites per single host, for example.

\section{ADULT MOQUITO POPULATION}

Disease transmission is directly influenced by vector density, i.e. more mosquitoes in a given area would probably represent a higher risk of dengue transmission than where mosquito population is at low levels. Vector population density is often observed during short time series, by field collection of eggs, immature or adult mosquitoes (Focks 2003). In this sense, the use of traps to sample mosquitoes has gained adepts in order to enhance the effectiveness of collection and to reduce the labor-intensive activity of active searching flying mosquitoes (Maciel-deFreitas et al. 2008).

Ae. aegypti presents a remarkable seasonality in their density population, with peaks generally associated with the rainy summer. Vector density was evaluated by a detailed time series analysis in three neighborhoods of Rio de Janeiro and one of authors' conclusions was that weekly temperatures above $22-24^{\circ} \mathrm{C}$ were strongly associated with $A e$. aegypti abundance and, thus, on dengue transmission (Honório et al. 2009). The increase in daily temperatures may also reduce the development time of Ae. aegypti up to around one week after egg hatching (Tun-Lin et al. 2000). In addition, several abandoned containers can be filled with during intense rainfall observed in summer (Ribeiro et al. 2008). The Ae. aegypti eggs present high resistance to desiccation, for up to one year after being laid in artificial containers. It means that eggs laid in the field during few months will hatch together in the summer, when start raining. High temperatures would accelerate the immature development and adults would emerge more rapid than at low temperatures. At this point, we would probably have a strong generation overlapping effect, with an exponential increase on vector population density and also on risk of dengue transmission (Consoli \& Lourenço-de-Oliveira 1994, Ribeiro et al. 2008, Rezende et al. 2008, Honorio et al. 2009).

Vector density is usually high heterogeneous in urban metropolitan areas. However, a common sense associates higher infestation levels with high human density, a hypothesis that is reinforced with data gathered in USA and Brazil (Tinker 1964, von Windeguth et al. 1969). After surveying more than 440 communities in 262 counties, Tinker (1964) observed infestation rates were significantly higher in substandard areas, mainly due to the great number of water-holding containers in comparison with standard areas. In Rio de Janeiro, high infestation levels were observed in neighborhoods with irregular water distribution, garbage collection and low urban organization (Maciel-de-Freitas et al. 2007a). On the other hand, a significant lower infestation was observed in a neighborhood with piped water, frequent garbage collection and standard urban organization (David et al. 2009).

\section{EXTRINSIC INCUBATION PERIOD (EIP)}

The EIP is commonly defined as the time elapsed between Ae. aegypti female blood-feeding on an infected host and the arrival of dengue virus in the mosquito salivary gland (Gubler \& Kuno 1997). Theoretically, the EIP on the Ae. aegypti - dengue 
system is pointed to last 14 days (Gubler \& Kuno 1997). However, recent evidences have showed that some Ae. aegypti females already have dengue virus on their salivary gland on the fourth day after receiving an infectious blood-meal (Salazar et al. 2007). Just as in other arboviruses, the replication dynamic of dengue virus in orally infected mosquitoes depends basically on ambient temperature, mosquito and virus strains and on the viral titer during bloodfeeding (Rodhain \& Rosen 1997). When dengue virus is ingested by an Ae. aegypti during blood feeding upon a viraemic host, virus replication is constrained to the midgut cells, since the virus passes into the lumen of the hind part of the mid-gut of the mosquito as part of the blood meal (Mellor 2000). In a few days after the ingestion of infectious blood-meal, the virus invades afterwards foregut, fat bodies, hemocytes and neural tissues (Mellor 2000, Salazar et al. 2007). Finally, the virus may be observed in mosquito brain, thoracic and abdomen nervous ganglion and salivary glands, besides the above mentioned organs (Rodhain \& Rosen 1997, Salazar et al. 2007). The replication dynamics of dengue virus in Ae. aegypti seems to be a disseminated process, since viral RNA may be found even in somatic tissues like mosquito legs (Alto et al. 2008).

The ambient temperature has a relevant role in the determination of the EIP duration. Watts et al. (1987) have observed an EIP duration of 12 days when mosquitoes were kept at constant temperature under $30^{\circ} \mathrm{C}$ and of just seven days when room temperature was between 32 and $35^{\circ} \mathrm{C}$. Therefore, it is often accepted that the EIP would be longer at lower temperatures due to the low viral replication at this condition (Watts et al. 1987).

\section{PROBABILITY OF DAILY SURVIVAL (PDS) RATE}

The survival of Ae. aegypti has been intensely addressed in laboratory controlled assays (Day et al. 1994, Naksathit \& Scott 1998, Costero et al. 1998, Canyon et al. 1999, Costero et al. 1999, Briegel et al. 2001, Maciel-de-Freitas et al. 2007b). Under field conditions, often using markrelease-recapture experiments, marked females of Ae. aegypti were collected up to 43 days after release day (Trpis \& Hausermann 1975, 1986, Trpis et al. 1995).

Traditionally, the PDS has been seen as constant and age-independent, despite the fact that some recent evidences had pointed that the mosquito mortality might vary with age (Buonacoorsi et al. 2003, Styer et al. 2007a, 2007b, Harrington et al. 2008). Despite the recent advances in this topic, the PDS of Ae. aegypti was for several decades estimated by mark-release-experiments, a technique first used to estimate anopheline PDS and largely extrapolated to other vectors (Gillies 1961). It is often assumed that mosquitoes generally die by predation or climatic factors rather than age, what supported the use of models where mortality was age-independent to estimate vector PDS (McDonald 1952). Using data from a mark-release-recapture experiment conducted in Africa (McDonald 1977), Clements and Paterson (1981) observed that Ae. aegypti mortality rate was constant and, then, might be estimated by the use of an exponential model firstly proposed by Gillies (1961).

By conducting a mark-release-experiment of Anopheles gambiae in Africa, the exponential model was first used to estimate vector PDS under natural conditions (Gillies 1961). Since then, this model has been largely used in mark-release-recapture studies of several vector species (Gillies \& Wilkes 1965, Wada et al. 1969, Sheppard et al. 1969, Dow 1971, McDonald 1977, Seawright et al. 1977, Reisen et al. 1978, 1980, Nayar 1981, 1982, Haramis \& Foster 1983, Linthicum et al. 1985, Walker et al. 1987, Rodriguez et al. 1992, Constantini et al. 1996, Morrison et al. 1999, Maciel-de-Freitas et al. 2007c).

According to Harrington et al. (2001), the exponential model proposed by Gillies (1961) is one of the few applicable to mosquito species that not present gonotrophic concordance, as Ae. aegypti. We classify a female as having gonotrophic concordance when one blood-meal corresponds to one oviposition cycle. Females from species with gonotrophic discordance frequently need more than one bloodmeal to perform egg laying (Consoli \& Lourenço-deOliveira 1994). However, the exponential method still deals with vector mortality as being age-independent (Harrington et al. 2001).

An interesting and relevant aspect of Ae. aegypti daily survival would be its longevity. This parameter 
is expressed in days and has a deep connection with the PDS (Niebylski \& Craig 1994). The mean life expectancy would be the number of days of mosquitoes survival, considering the calculated PDS. For instance, in order to evaluate the frequency of $A e$. aegypti that survive the dengue incubation period, one might perform PDSn (where $\mathrm{n}$ is the EIP of dengue in Ae. aegypti, according to Salazar et al. 2007).

In Rio de Janeiro, Ae. aegypti survival and longevity were evaluated during dry and wet seasons, in neighborhoods with distinct social-economic and urbanized settlements (Maciel-de-Freitas et al. 2007c, David et al. 2009). A mark-release-recapture was used to observe that the mosquito did not survival between those seasons. However, mosquitoes presented a significantly higher PDS in a typical Brazilian slum than in a suburban area (Maciel-de-Freitas et al. 2007c). Authors suggested that mosquitoes would be less exposed to host parasite defensive behavior and climatic factors in the slum due the higher human density observed there. Host abundance would reduce mosquito dispersal and also their mortality (Macielde-Freitas et al. 2007b, 2010). However, conclusions regarding a correlation between Ae. aegypti survival and human density or degree of urbanization or social-economic status must be taken carefully, since just a few neighborhoods were evaluated.

Acommon source of bias in mark-release-recapture experiments is the spatial homogeneity of capture sites within the study areas. The capture effort must be equally distributed through the study site, otherwise survival estimates might be biased. Another common issue during mark-release-recapture experiments is to disentangle mortality from emigration. After releasing a known number of marked mosquitoes, it is natural to observe a decline in daily collections of marked individuals. However, the short lifespan of Ae. aegypti, for instance, turns laborious to estimate mosquito emigration from the study site and mortality rates together. Thus, after two or three days without capturing any marked individual, field researchers often assume that the released individuals are not available for being captured, independent of their death or emigration (Maciel-de-Freitas et al. 2007b, 2010, David et al. 2009).

One aspect that might change vector survival and must be fully addressed is the hypothesis that infected individuals have a fitness loss due to infection.
Previously, it was observed that Ae. aegypti infected with DENV-2 survived less than uninfected females (Joshi et al. 2002). A recent research paper performed a meta-analysis and showed that Ae. aegypti survival is generally low affected by arbovirus infection (Lambrechts \& Scott 2009). Individuals infected with DENV-2 presented a significant negative impact on their longevity, survivorship and fecundity, which are important parameters for mosquito fitness (Macielde-Freitas, unpublished data). Actually, fitness loss due to arbovirus infection has already been detected in Ae. triseriatus infected with La Crosse (Grimstad et al. 1980), Culiseta melanura with Eastern Equine Encephalitis (Scott \& Lorenz 1998) and Culex tarsalis infected with Western Equine Encephalitis (Lee et al. 2000). Remarkably, arboviral infection might modify several aspects of vectors' ability to transmit the pathogen, such as their blood-feeding behavior, longevity, fecundity and survival rates. Therefore, the implication of these changes due to infection must be addressed in vector-parasite systems, such as $A e$. aegypti-dengue virus.

\section{CONCLUSIONS}

The vectorial capacity is a useful tool to evaluate the ability of an insect population in transmitting a pathogen. However, there are several sources of bias in the estimation of their parameters, what would influence the conclusions achieved by field researchers and public health decision makers.

\section{REFERENCES}

ALTO, B.W; REISKIND, M. \& LOUNIBOS, L.P. 2008. Size alters susceptibility of vectors to dengue virus infection and dissemination. American Journal of Tropical Medicine and Hygiene, 79: 688-695.

ARUNACHALAN, N.; TEWARI, S.C.; THENMOZHI, V.; RAJENDRAN, R.; PARAMASIVAN, R.; MANAVALAN, R.; AYANAR, K. \& TYAGI, B.K. 2008. Natural vertical transmisión of dengue virases by Aedes aegypti in Chennai, Tamil Nadu, India. Indian Journal of Medical Research, 127: 395-397.

ATKINSON, M.P.; ALPHEY, N.; ALPHEY, L.S.; COLEMAN, P.G. \& WIEN, L.M. 2007. Analyzing the control of mosquito- 
borne diseases by a dominat lethal genetic system. Proceedings of the National Academy of Science USA, 104: 9540-9545.

BOSIO, C.F.; FULTON, R.E.; SALASEK, M.L.; BEATY, B.J. \& BLACK, W.C. 2000. Quantitative trait loci that control vector competence for dengue-2 virus in the mosquito Aedes aegypti. Genetics, 156: 687-698.

BRAKS, M.A.H.; HONORIO, N.A.; LOURENÇO-DEOLIVEIRA, R.; JULIANO, S.A. \& LOUNIBOS, L.P. 2003. Convergent habitat segregation of Aedes aegypti and Aedes albopictus (Diptera: Culicidae) in southeastern Brazil and Florida. Journal of Medical Entomology, 40: 785-794.

BRIEGEL, H; KNÜSEL, I \& TIMMERMANN, S.E. 2001. Aedes aegypti: size, reserves, survival, and flight potential. Journal of Vector Ecology, 26: 21-31.

BUONACCORSI, J.P.; HARRINGTON, L.C. \& EDMAN, J.D. 2003. Estimation and comparison of mosquito survival rates with release-recapture-removal data. Journal of Medical Entomology, 40: 6-17.

CANYON, D.V.; HII, J.L.K. \& MULLER, R. 1999. Effect of diet on biting, oviposition, and survival of Aedes aegypti (Diptera: Culicidae). Journal of Medical Entomology, 36: 301-308.

CLEMENTS, A.N. \& PATERSON, G.D. 1981. The analysis of mortality and survival rates in wild populations of mosquitoes. Journal of Applied Ecology, 18: 373-399.

CLEMENTS, A.N. 1999. The Biology of Mosquitoes, Vol. 1: Development, nutrition and reproduction. Chapmanl Hall, London. 536p.

CONSOLI, R.A.G.B. \& LOURENÇO-DE-OLIVEIRA, R. 1994. Principais Mosquitos de Importância Sanitária no Brasil. Fiocruz, Rio de Janeiro, RJ. 228p.

CONSTANTINI, C.; LI, S.; TORRE, A.D.; SAGNON, N.; COLUZZI, M. \& TAYLOR, C.E. 1996. Density, survival and dispersal of Anopheles gambiae complex mosquitoes in a West African Sudan savanna village. Medical and Veterinary Entomology, 10: 203-219.

COSTERO, A.; EDMAN, J.D.; CLARK, G.G. \& SCOTT, T.W. 1998. Life table study of Aedes aegypti (Diptera: Culicidae) in Puerto Rico fed only human blood versus blood plus sugar. Journal of Medical Entomology, 35: 809-813.

COSTERO, A.; EDMAN, J.D.; CLARK, G.G.; KITTAYAPONG, P. \& SCOTT, T.W. 1999. Survival of starved Aedes aegypti
(Diptera: Culicidae) in Puerto Rico and Thailand. Journal of Medical Entomology, 36: 272-276.

CUNHA, S.P.; ALVES, J.C.R; LIMA, M.M.; DUARTE, J.R.; BARROS, L.C.V.; SILVA, J.L.; GAMARRO, A.T.; MONTEIROFILHO, O.S. \& WANZELER, A.R. 2002. Presença de Aedes aegypti em bromeliaceae e depósitos com plantas no Município de Rio de Janeiro. Revista de Saúde Pública, 36: 244-245.

DAVID, M.R.; LOURENÇO-DE-OLIVEIRA, R. \& MACIELDE-FREITAS, R. 2009. Container productivity daily survival rates and dispersal ofAedes aegypti mosquitoes in a high income dengue epidemic neighborhood in Rio de Janeiro: presumed influence of differential urban structure no mosquito biology. Memórias do Instituto Oswaldo Cruz, 104: 927- 932.

DAY, J.F. \& EDMAN, J.D. 1983. Malaria renders mice susceptible to mosquito feeding when gametocytes are most infective. Journal of Prasitology, 69: 163-170.

DAY, J.F.; EBERT, K.M. \& EDMAN, J.D. 1983. Feeding patterns of mosquitoes (Diptera: Culicidae) simultaneously exposed to malarious and healthy mice. Journal of Medical Entomology, 20: 120-127.

DAY, J.F.; EDMAN, J.D. \& SCOTT, T.W. 1994. Reproductive fitness and survivorship of Aedes aegypti (Diptera: Culicidae) maintained on blood, with field observations from Thailand. Journal of Medical Entomology, 31: 611-617.

DOW, R.P. 1971. The dispersal of Culex nigripalpus marked with high concentrations of radiophosphorus. Journal of Medical Entomology, 30: 353-363.

DYE, C. 1990. Epidemiological significance of vector-parasite interactions. Parasitology 101: 409-415. Journal of Medical Entomology, 8: 353-363.

EDMAN, J.D.; STRICKMAN, D.; KITTAYAPONG, P \& SCOTT, T.W. 1992. Female Aedes aegypti (Diptera: Culicidae) in Thailand rarely feed on sugar. Journal of Medical Entomology, 29: 1035-1038.

FOCKS, D.A. 2003. A review of entomological sampling methods and indicators for dengue vectors. UNICEF / UNDP / World Bank / WHO Special program for research and training in tropical diseases (TDR). World Health Organization, Geneva. $40 \mathrm{p}$.

FOCKS, D.A.; BRENNER, R.A.; DANIELS, E. \& HAYES, J. 2000. Transmission threshold for dengue in terms of Aedes 
aegypti pupae per person with discussion of their utility in source reduction efforts. American Journal of Tropical Medicine and Hygiene, 62: 11-18.

GARRET-JONES, C. 1964. The human blood index of malaria vectors in relation to epidemiological assessment. Bulletin of the World Health Organization, 30: 241-261.

GILLIES, M.T. 1961. Studies on the dispersion and survival of Anopheles gambiae Giles in East Africa, by means of marking and releasing experiments. Bulletin of Entomological Research, 52: 99-127.

GILLIES, M.T. \& WILKES, T.J. 1965. A study of the age composition of populations of Anopheles gambiae Giles and An. funestus Giles in northeastern Tanzania. Bulletin of Entomological Research, 56: 237-262.

GRIMSTAD，P.R.; ROSS， Q.E. \& CRAIG， G.B. 1980 Aedes triseriatus (Diptera: Culicidae) and La Crosse virus. II. Modification of mosquito feeding behavior by vírus infection. Journal of Medical Entomology, 31: 1-7.

GUBLER, D.J. \& KUNO, G. 1997. Dengue and dengue hemorrhagic fever. CAB International. Wallingford, United Kingdom. 496p.

GUBLER, D.J. \& ROSEN, L. 1976. A simple technique for demonstrating transmission of dengue virus by mosquitoes without the use of vertebrate hosts. American Journal of Tropical Medicine and Hygiene, 25: 146-150.

HARAMIS, L.D. \& FOSTER, W.A. 1983. Survival and population density of Aedes triseriatus (Diptera: Culicidae) in a wood lot in central Ohio, USA. Journal of Medical Entomology, 20: 391-398.

HARDY, J.L. 1988. Susceptibility and resistance of vector mosquitoes. Pp. 87-126. In: T.P. Monath (ed.). Epidemiology and Ecology. CRC Press, Boca Raton, Florida, USA. 280p.

HARRINGTON, L.C.; BUONACCORSI, J.P.; EDMAN, J.D.; COSTERO, A.; KITTAYAPONG, P.; CLARK, G.G. \& SCOTT, T.W. 2001. Analysis of survival of young and old Aedes aegypti (Diptera: Culicidae) from Puerto Rico and Thailand. Journal of Medical Entomology, 398: 537-547.

HARRINGTON, L.C.; VERMEYLEN, F.; JONES, J.J.; KITHAWEE, S.; SITHIPRASASNA, R. EDMAN, J.D. \& SCOTT, T.W. 2008. Age-dependent survival of the dengue vector Aedes aegypti (Diptera: Culicidae) demonstrated by simultaneous release-recapture of different age cohorts. Journal of Medical Entomology, 45: 307-313.

HOLMES, E.C. \& BURCH, S.S. 2000. The causes and consequences of genetic variation in dengue virus. Trends in Microbiology, 8: 74-77.

HONÓRIO, N.A.; CODEÇO, C.T.; ALVES, F.C., MAGALHAES, M.A.F.M. \& LOURENÇO-DE-OLIVEIRA, R. 2009. Temporal distribution of Aedes aegypti in three different districts of Rio de Janeiro, Brazil, measured by two types of traps. Journal of Medical Entomology, 46: 1001-1014.

JOSHI, V.; MOURYA, D.T. \& SHARMA, R.C. 2002. Persistence of dengue-3 virus through transovarial transmission passage in successive generations of Aedes aegypti mosquitoes. American Journal of Tropical Medicine and Hygiene, 67: 158-161.

KLEMPNER, M.S.; UNNASCH, T.R. \& HU, L.T. 2007. Taking a bite out of vector-transmited infectious diseases. New England Journal of Medicine, 356: 2567-2569.

KUNO, G. 1995. Review of the factors modulating dengue transmission. Epidemiologic Reviews, 17: 321-335.

LAMBRECHTS, L. \& SCOTT, T.W. 2009. Mode of transmission and the evolution of arbovirus virulence in mosquito vectors. Proceedings of the Royal Society of London B, 276: 1369-1378.

LEA, A.O.; DIMOND, J.B. \& DELONG, D.M. 1956. Role of diet in egg development by mosquitoes (Aedes aegypti). Science, 123: $890-891$

LEE, J.H.; ROWLEY, W.A. \& PLATT, K.B. 2000. Longevity and spontaneous flight activity of Culex tarsalis (Diptera: Culicidae) infected with wetern equine encephalomyelitis virus. Journal of Medical Entomology, 37: 187-193.

LINTHICUM, K.J.; BAILEY, C.L.; DAVIES, F.G. \& KAIRO, A. 1985. Observations on the dispersal and survival of a population of Aedes lineatopennis (Ludlow) (Diptera: Culicidae) in Kenya. Bulletin of Entomological Research, 75: 661-670.

LOURENÇO-DE-OLIVEIRA，R.; VAZEILLE，M.; FILLIPS, A.M.B. \& FAILLOUX, A.B. 2004. Aedes aegypti in Brazil: genetically differentiated populations with high susceptibility to dengue and yellow fever viruses. Transactions of the Royal Society of Tropical Medicine and Hygiene, 98: 43-54.

LUZ, P.M.; CODEÇO, C.T.; MASSAD, E. \& STRUCHINER, C.J. 2003. Uncertainties regarding dengue modeling in Rio de 
Janeiro, Brazil. Memórias do Instituto Oswaldo Cruz, 97: 871-878.

MACDONALD, W.M. 1956. Aedes aegypti in Malaya. 1. Distribution and dispersal. Annals of Tropical Medicine and Parasitology, 50: 385-398.

MACIEL-DE-FREITAS, R.; MARQUES, W.A.; PERES, R.C.; CUNHA, S.P \& LOURENÇO-DE-OLIVEIRA, R. 2007a. Variation in Aedes aegypti (Diptera: Culicidae) container productivity in a slum and a suburban district in Rio de Janeiro during dry and wet seasons. Memórias do Instituto Oswaldo Cruz, 102: 489-496.

MACIEL-DE-FREITAS, R.; CODEÇO, C.T. \& LOURENÇODE-OLIVEIRA, R. 2007b. Daily survival rates and dispersal of Aedes aegypti females in Rio de Janeiro, Brazil. American Journal of Tropical Medicine and Hygiene, 76: 659- 665.

MACIEL-DE-FREITAS, R; CODEÇO, C.T. \& LOURENÇODE-OLIVEIRA, R. 2007c. Body size associated survival and dispersal rates of Aedes aegypti in Rio de Janeiro. Medical and Veterinary Entomology, 21: 284-292.

MACIEL-DE-FREITAS, R; PERES, R.C.; ALVES，F. \& BRANDOLINI, M.B. 2008. Mosquito traps designed to capture Aedes aegypti (Diptera: Culicidae) females: preliminary comparison of Adultrap, MosquiTRAP and backpack aspirator efficiency in a dengue-endemic area of Brazil. Memórias do Instituto Oswaldo Cruz, 103: 602-605.

MACIEL-DE-FREITAS, R; SOUSA-SANTOS, R; CODEÇO, C.T. \& LOURENÇO-DE-OLIVEIRA, R. 2010. Influence of the spatial distribution of human hosts and large size containers on the dispersal of the mosquito Aedes aegypti within the first gonotrophic cycle. Medical and Veterinary Entomology, 24: 74-82.

MCDONALD, P.T. 1952. The analysis of sporozoite rate. Tropical Disease Bulletin, 49: 569-585.

MCDONALD, P.T. 1977. Population characteristics of domestic Aedes aegypti (Diptera: Culicidae) in villages on the Kenya coast. I - Adult survivorship and population size. Journal of Medical Entomology, 14: 42-48.

MELLOR, P.S. 2000. Replication of arboviruses in insect vectors. Journal of comparative Pathology, 123: 231-247.

MILLER, B.R. \& MITCHELL, C.J. 1991. Genetic selection of a flavivirus-refractory strain of the yellow fever mosquito Aedes aegypti. American Journal of Tropical Medicine and Hygiene, 45: 399-407.
MORRISON, A.C.; COSTERO, A.; EDMAN, J.D.; CLARK, G.G. \& SCOTT, T.W. 1999. Increased fecundity of Aedes aegypti (Diptera: Culicidae) fed human blood prior to release in a mark recapture study in Puerto Rico. Journal of the American Mosquito Control Association, 15: 98-104.

NAKSATHIT, A.T. \& SCOTT, T.W. 1998. Effect of female size on fecundity and survivorship of Aedes aegypti fed only human blood versus human blood plus sugar. Journal of the American Mosquito Control Association, 14: 148-152.

NAKSATHIT, A.T.; EDMAN, J.D. \& SCOTT, T.W. 1999a. Amounts of glycogen, lipid, and sugar in adult female Aedes aegypti (Diptera: Culicidae) fed sucrose. Journal of Medical Entomology, 36: 8-12.

NAKSATHIT, A.T.; EDMAN, J.D. \& SCOTT, T.W. $1999 \mathrm{~b}$. Utilization of human blood and sugar as nutrients by female Aedes aegypti (Diptera: Culicidae). Journal of Medical Entomology, 36 : 13-17.

NAKSATHIT, A.T.; EDMAN, J.D. \& SCOTT, T.W. 1999c. Partitioning of glycogen, lipid, and sugar in ovaries and body remnants of female Aedes aegypti (Diptera: Culicidae) fed human blood. Journal of Medical Entomology, 36: 18-22.

NASCI, R.S. \& MITCHELL, C.J. 1994. Larval diet, adult size, and susceptibility of Aedes aegypti (Diptera: Culicidae) to infection with Ross River virus. Journal of Medical Entomology, 31: $123-126$.

NATHAN, M.B. \& DAYAL-DRAGER, R. 2007. Recent epidemiological trends, the global strategy and public health advances in dengue. Report on Dengue, Scientific Working Group, World Health Organization, Geneva. 168p.

NAYAR, J.K. 1981. Aedes aegypti (L.) (Diptera: Culicidae): Observations on dispersal, survival, insemination, ovarian development and oviposition characteristics of a Florida population. Journal of Florida Anti-Mosquito Control Association, 52: 24-40.

NAYAR, J.K. 1982. Wyeomyia mitchelli: Observations on dispersal, survival, insemination, ovarian development and oviposition characteristics of a Florida population. Mosquito News, 42: 416-427.

NEWTON, A.C. \& REITER, P. 1992. A model of the transmission of dengue fever with an evaluation of the impact of ultra-low volume (UBV) insecticide applications on dengue epidemics. American Journal of Tropical Medicine and Hygiene, 47: 709720. 
NYEBYLSKI, M.L. \& CRAIG, G.B. 1994. Dispersal and survival of Aedes albopictus at a scrap tire yard in Missouri. Journal of the American Mosquito Control Association, 10: 339-343.

PERYASSÚ, A.G. 1908. Os Culicideos do Brasil. Instituto de Manguinhos, Rio de Janeiro, Brasil. 407 p.

PLATT, K.B.; LINTHICUM, K.J.; MYINT, K.S.A., INNIS, B.L.; LERDTHISNEE, K. \& VAUGHN, D.W. 1997. Impact of dengue virus infection on feeding behavior of Aedes aegypti. American Journal of Tropical Medicine and Hygiene, 57: 119-125.

PUTNAM, J.L. \& SCOTT, T.W. 1995. Blood-feeding behavior of dengue-2 virus-infected Aedes aegypti. American Journal of Tropical Medicine and Hygiene, 52: 225-227.

REISEN, W.K.; ASLAM, A.; SIDDIQUI, T.F. \& KHAN, A.Q. 1978. A mark-release-recapture experiment with Culex tritaeniorhincus Giles. Transactions of the Royal Society of Tropical Medicine and Hygiene, 72: 167-177.

REISEN, W.K.; MAHMOOD, F. \& PARVEEN, T. 1980. Anopheles culcifacies Giles: a release recapture experiment with cohorts of known age with implications for malaria epidemiology and genetical control in Pakistan. Transactions of the Royal Society of Tropical Medicine and Hygiene, 74: 307-317.

REZENDE, G.L.; MARTINS, A.J.; GENTILE, C.; FARNESI, L.C., PELAJO-MACHADO, M.; PEIXOTO, A.A., VALLE, D. 2008. Embryonic desiccation resistance in Aedes aegypti: presumptive role of the chitinized sersoal cuticle. BMC Developmental Biology, 8: 82.

RHODAIN, F. \& ROSEN, L. 1997. Mosquito vectors and dengue virus-vector relationships. Pp. 45-60. In: D.J. Gubler \& G. Kuno (eds.). Dengue and dengue hemorrhagic fever. CAB International. Wallingford, United Kingdom. 496p.

RIBEIRO, A.F.; MARQUES, G.R.A.M.; VOLTOLINI, J.C. \& CONDINO, M.L.F. 2008. Associação entre incidência de dengue e variáveis climáticas. Revista de Saúde Pública, 40: 671-676.

RIGÁU-PEREZ, J.G.; CLARK, G.G.; GUBLER, D.J.; REITER, P.; SANDERS, E.J. \& VORNDAN, A.V. 1998. Dengue and dengue haemorrhagic fever. The Lancet, 352: 971-977.

RODRIGUEZ, M.H.; BOWN, D.N.; ARREDONDO-JIMENEZ, A.D.; VILLAREAL, C.; LOYOLA, E.G. \& FREDERICKSON, D.E. 1992. Gonotrophic cycle and survivorship of Anopheles albimanus (Diptera: Culicidae) in southern Mexico. Journal of Medical Entomology, 29: 395-399.
ROSSIGNOL, P.A.; RIBEIRO, J.M.C.; JUNGERY, M.; TURELL, M.J.; SPIELMAN, A \& BAILEY, C.L. 1985. Enhanced mosquito blood-finding success on parasitemic hosts: evidence for vectorparasite mutualism. Proceedings of the National Academy of Science USA, 82: 7725-7727.

ROTHMAN, A.L. 1997. Viral pathogenesis of infection. Pp. 245-271. In: D.J. Gubler \& G. Kuno (eds.). Dengue and Dengue Hemorrhagic Fever. CABI International, New York. 496p.

SALAZAR, M.I.; RICHARDSON, J.H.; SÁNCHEZ-VARGAS, I.; OLSON, K.E. \& BEATY, B.J. 2007. Dengue virus type 2: replication and tropisms in orally infected Aedes aegypti mosquitoes. BMC Microbiology, 7: 9.

SCOTT, T.W.; CLARK, G.G.; AMERASINGUHE, P.H.; LORENZ, L.H.; REITER, P. \& EDMAN, J.D. 1993. Detection of multiple blood feeding patterns in Aedes aegypti (Diptera: Culicidae) during a single gonotrophic cycle using a histological technique. Journal of Medical Entomology, 30: 94-99.

SCOTT, T.W.; NAKSATHIT, A.; DAY, J.P.; KITTAYAPONG, P. \& EDMAN, J.D. 1997. A fitness advantage for Aedes aegypti and the virus it transmits when females fed only on human blood. American Journal of Tropical Medicine and Hygiene, 57: 235-239.

SCOTT, T.W. \& LORENZ, L.H. 1998. Reduction of Culiseta melanura fitness by eastern equine encephalomyelitis virus. American Journal of Tropical Medicine and Hygiene, 59: 341-346.

SCOTT, T.W.; AMERASINGUHE, P.H.; MORRISON, A.C.; LORENZ, L.H.; CLARK, G.G.; STRICKMAN, D.; KITTAYAPONG, P. \& EDMAN, J.D. 2000. Longitudinal studies of Aedes aegypti (Diptera: Culicidae) in Thailand and Puerto Rico: Blood feeding frequency. Journal of Medical Entomology, 37: 89-101.

SEAWRIGHT, J.A.; DAME, D.A. \& WEIDHASS, D.E. 1977. Field survival and ovipositional characteristics of Aedes aegypti and their relation to population dynamics and control. Mosquito News, 37: 62-70.

SERVICE, M.W. 1993. Mosquito ecology: field sampling methods. Second Edition. Elsevier, London. 1007p.

SHEPPARD, P.M.; MACDONALD, W.W.; TONN, R.J. \& GRABS, B. 1969. The dynamics of an adult population of Aedes aegypti in relation to dengue haemorrhagic fever in Bangkok. Journal of Animal Ecology, 38: 661-702. 
STYER, L.M.; CAREY, J.R.; WANG, L.M. \& SCOTT, T.W. 2007a. Mosquitoes do senesce: departure from the paradigm of constant mortality. American Journal of Tropical Medicine and Hygiene, 76: 111-117.

STYER, L.M.; MINNICK, S.L.; SUN, A.K. \& SCOTT T.W. 2007b. Mortality and reproductive dynamics of Aedes aegypti (Diptera: Culicidae) fed human blood. Vector Borne Zoonotic Disease, 7: 86-98.

THENMOZHI, V.; TEWARI, S.C.; MANAVALAN, R.; BALASUBRAMANIAN, A. \& GAJANANA, A. 2000. Natural vertical transmission of dengue viruses in Aedes aegypti in southern Índia. Transactions of the Royal Society of Tropical Medicine and Hygiene, 94: 507.

TINKER, M.E. 1964. Larval habitat of Aedes aegypti (L.) in the United States. Mosquito News, 24: 426-432.

TRPIS, M. \& HAUSERMANN, W. 1975. Demonstration of differential domesticity of Aedes aegypti in an African village and their possible significance in epidemiology of vector-borne disease. American Journal of Tropical Medicine and Hygiene, 25: 238-245.

TRPIS, M. \& HAUSERMANN, W. 1986. Dispersal and others population parameters of Aedes aegypti in an African village and their possible significance in epidemiology of vector-borne disease. American Journal of Tropical Medicine and Hygiene, 35: 1263-1279.

TRPIS, M.; HAUSERMANN, W. \& CRAIG, G.B. 1995. Estimates of population size, dispersal, and longevity of domestic Aedes aegypti (Diptera: Culicidae) by mark-release-recapture in the village of Shauri Moyo in eastern Kenya. Journal of Medical Entomology, 32: 27-33.

TUN-LIN, W.; BURKOT, T.R. \& KAY, B.H. 2000. Effects of temperature and larval diet on development rates and survival of the dengue vector Aedes aegypti in north Queensland, Australia. Medical and Veterinary Entomology, 14: 31-37.

TURELL, M.J. \& BAILEY, C.L. 1987. Transmission studies in mosquitoes (Diptera: Culicidae) with disseminated Rift Valley Fever virus infections. Journal of Medical Entomology, 24: 11-18.

VON WIDEGUTH, D.L.; ELIASON, D.A.; KILPATRICK, J.W. \& JACOB, W.L. 1969. The transitory nature of Aedes aegypti larval habitats in an urban situation. Mosquito News, 29: 495-496.
WADA, Y.; KAWAI, S.; ODA, T.; MIYAGY, I. SUENAGA, O. MISHIGAKI, J. \& OMORI, N. 1969. Dispersal experiment of Culex tritaeniorhyncus in Nagasaki área (preliminary report). Tropical Medicine, 11: 37-44.

WALKER, E.D.; COPELAND, R.S.; PAULSON, S.L. \& MUNSTERMANN, L.E. 1987. Adult survivorship, population density, and body size in sympatric populations of Aedes triseriatus and Aedes hendersoni (Diptera: Culicidae). Journal of Medical Entomology, 24: 485-493.

WARREL, W.A. \& GILLES, H.M. 2002. Essential Malariology. Fourth Edition. Hodder Arnold Publication. 384p.

WATTS, D.M.; BURKE, D.S.; HARRISON, B.A.; WHITMIRE, R.E. \& NISALAK, A. 1987. Effect of temperature on the vector efficiency of Aedes aegypti for dengue 2 virus. American Journal of Tropical Medicine and Hygiene, 36: 143-152.

WOODRING, J.L.; HIGGS, S. \& BEATY, B.J. 1996. Natural cycles of vector borne pathogens. Pp. 51-72. In: W.C. Marquadt $\&$ B.J. Beaty (eds.). Biology of Disease Vectors. University Press of Colorado, CO, USA. 816p.

Submetido em 28/03/2010

Aceito em 27/07/2010 